\title{
Association between Nitric Oxide (Sputum Induction and Asthma Control Level on Asthma Outpatients
}

\author{
Andi Yanti ${ }^{1}$, Muhammad Aminuddin ${ }^{2}$ \\ ${ }^{1}$ Students of Department of Pulmonology and Respiratory,Faculty of Medicine, Universitas Airlangga, Jalan \\ Mayjen. Prof Dr. Soetomo 47 Surabaya 60131, Indonesia, 2Lecture of Department of Pulmonology and \\ Respiratory, Faculty of Medicine, Dr. Soetomo Teaching Hospital, Universitas Airlangga
}

\begin{abstract}
Background: Asthma is a heterogeneous disease with chronic inflammatory characteristics of the respiratory tract. (Nitric Oxide) (NO) levels increased significantly in patients with inflammation such as asthma in this study. Nitric Oxide (NO) levels in normal people and asthma patients are different, but no sputum of Nitric Oxide (NO) levels are associated with asthma control levels.

Method: Thirty-patients consecutive sampling was conducted at asthma unit Dr. Soetomo Teaching Hospital Surabaya. The subjects were met the inclusion and exclusion criteria that assessed their asthma control with asthma control test (ACT) then measured by NO levels.

Results: In this study, the subjects were divided into asthma control level; full-controlled was 4 subjects $(13,3 \%)$, partially-controlled was 8 subjects $(26,7 \%)$, and uncontrolled was 18 subjects $(60,0 \%)$. The mean asthma control level was $18.3 \pm 4.2$ with the lowest Asthma control test (ACT) score was 8 and the highest ACT score was 25 . The mean NO sputum induction level was $92.043 \pm 29.040 \mu \mathrm{M}$, with the lowest NO was $14.566 \mu \mathrm{M}$ and the highest NO was $138.350 \mu \mathrm{M}$. The result of the statistical test showed a negative correlation significantly between NO-induced sputum level and asthma control level $(p<0,05)$.
\end{abstract}

Conclusion: The examination of NO sputum level could be used as an indicator in determining the level of asthma control.

Keywords: Asthma, nitric oxide, induced sputum levels, asthma control level, asthma control test score.

\section{Introduction}

Asthma is a heterogeneous disease with chronic inflammatory characteristics of the respiratory tract. This diagnosis is based on a history of respiratory symptoms such as wheezing, shortness of breath, heavy chest, and cough with long and intense time, along with the limitation of expiratory airflow. ${ }^{(1)}$ An estimated 300 million people worldwide are suffering from asthma.

\section{Corresponding Author:}

\section{Muhammad Aminuddin}

Lecture of Department of Pulmonology and Respiratory, Faculty of Medicine, Dr. Soetomo Teaching Hospital, Universitas Airlangga e-mail: muhammadaminudin978@gmail.com
The rates of global prevalence of asthma was $1 \%$ to $18 \%$ over various countries ${ }^{(1)}$., it mentioned that asthma prevalence was $4 \%{ }^{(2)}$ (Basic Health Research data In Indonesia 2007). Although asthma was not the main cause of death the impact of illness on asthma causes work productivity to decrease due to absent from work or school. Mortality rates in asthma increase steadily over the time ${ }^{(3)}$. The 1986 Household Health Survey (QRT) showed that asthma ranked fifth out of ten causes of morbidity along with chronic bronchitis and emphysema $^{(4)}$.

Diagnosis and monitoring of asthma are performed based on clinical symptoms, the degree of respiratory tract obstruction and bronchial hyperactivity. The clinical symptoms reported by the patient depending on the patient's perception and subjective, also the degree of respiratory tract obstruction that detected 
by the measurement of the expiratory peak (APE) or the first forced velocity (VEP1). Whereas, bronchial hyperactivity could be detected by stimulation (bronchial challenge test) such as histamine or methacholine and measure the function of the lung phase thereafter. International Guidelines recommend assessment of APE series or spirometry to establish the diagnosis of asthma. $^{(3),(4),(5),(6)}$

Nitric oxide (NO) plays an important role in the physiological function of the and as an indicator of respiratory tract inflammation. NO could be detected in the animal expiratory air. Some studies advocate NO assessment of expiratory air which is a noninvasive inflammatory marker in asthma. Mild asthma patients often provide normal values in VEP1, thus NO expiratory and sputum airborne measurements are proposed as noninvasive testing to assess respiratory tract inflammation in asthma. Bronchial challenge test for methacholine or histamine is a measure of bronchial hyperactivity, but it is difficult to assess the degree of inflammation $^{(6),(7),(8),(9),(10)}$

Research on the measurement of nitric oxide (NO) levels began to grow wider and NO levels increased significantly in patients with inflammation such as asthma $^{(8),(9)}$. Administration of corticosteroids lowering the NO levels in asthmatics and in air expiration that showed the correlation of the degree of respiratory tract hyperelastic and the number of eosinophils sputum. Thus, it could be used as a marker of respiratory tract inflammation and plays an important role in diagnosing asthma $^{(7)} \cdot 15$ people with asthma and 10 normal people get NO sputum rate of asthma patients was higher than control $(\mathrm{p}<0.01)(11)$. In another study from 23 samples studied, higher NO sputum levels were found in asthma compared to control $(p<0.01)(12)$. The Normal NO value of sputum is set $502 \mu \mathrm{mol} / \mathrm{L}$ with a standard deviation of 41413. The half-life of NO in the tissue is very short (about 1-5 seconds), the direct NO test is not easy to do so the examination is performed indirectly using Griess reaction. ${ }^{(13)}$.

Further research suggests that Nitric oxide (NO) levels of expiratory or sputum air could be used as a tool to monitor respiratory tract inflammation and assess whether asthma is controlled or not ${ }^{(7),(8),(9)}$. Although it is known that NO levels of normal people and asthma patients are different, NO sputum levels are associated with asthma control levels, especially in Dr. Soetomo Teaching Hospital, Surabaya Indonesia. Based on this background, then through this research, it will be examined about the correlation between induced sputum $\mathrm{NO}$ and asthma control level in asthma patients.

\section{Method}

This type of research was observational analytical cross-sectional. Research samples that met the inclusion criteria were; Patients who had diagnose bronchial asthma and control routinely in Asthma Unit/chronic obstructive pulmonary disease (COPD) Dr. Soetomo Teaching Hospital, Surabaya Indonesia (Age >15 y/o), do not consume food and drink containing nitrate 1 hour before nitric oxide (NO) test, Inhaled steroid users, Willing to participated the research also sign informed consent.

Materials needed consisting of sputum induction were $3 \% \mathrm{NaCl}, 0.1 \%$ DTT (dithiothreitol), phosphatebuffered saline solution, Eppendorf tube, sputum pot, and filter paper. Data analysis using SPSS 17.0 statistic program with significance level $p<0,05$. Analysis of the association between NO sputum induction of bronchial asthma with ACT score was used pearson correlation test while, comparative analysis of NO-induced sputum content with each group was used student T-test or ANOVA test.

\section{Results}

Normality Test: The result of the normality test of the research data variable was using the kolmogorov smirnov test. Table 1 explains that the kolmogorov smirnov test on the data of the research variables yielded a $p>0.05$. These results conclude that the study variable data were normally distributed.

Table 1. Normality Test

\begin{tabular}{|l|c|}
\hline Data & p Value \\
\hline Age $(\mathrm{y} / \mathrm{o})$ & 0.245 \\
BMI & 0.961 \\
FEV1/Pred (\%) & 0.955 \\
ACT score & 0.446 \\
No level $(\mu \mathrm{M})$ & 0.272 \\
\hline
\end{tabular}

BMI: Body Mass Index, FEV: First Forced Velocity, ACT: Asthma control test, NO: Nitric oxide

On the other hand, figure 4 describes the education of 30 research subjects, there were 11 people with high school education (36.7\%), 6 were undergraduate $(20.0 \%), 5$ of were an elementary school and junior high 
school (16.7\%), and 1 person educated were D3, D4 and S2, respectively (3.3\%).Figure 5 shows the body mass index BMI mean was 24.59, with the lowest was 16.23 and the highest was 36.44 , it was known that 2 subjects $(6.7 \%)$ were underweight, 14 subjects were normal weight, 11 subjects $(36,7 \%)$ were overweight, and 3 people $(10.0 \%)$ were obese. The first forced velocity FEV1/Pred average was 91.1\%, with the lowest FEV1/ Pred $42 \%$ and the highest FEV1/Pred 160\%.
Asthma Control Test (ACT) Score Correlation with NO Sputum Induction Level: Pearson correlation was used to find out whether there was a relationship between ACT scores with induced sputum NO levels. The result of pearson correlation between ACT score and NO-induced sputum level was in Table 5.

Table 2. Correlation of ACT Score with NO-induced sputum level

\begin{tabular}{|c|c|c|c|}
\hline & & & NO Level $(\boldsymbol{\mu M})$ \\
\hline \multirow{3}{*}{ Pearson correlation } & \multirow{3}{*}{ Skor ACT } & Correlation Coefficient & -0.562 \\
& & P-Value & 0.001 \\
& & $\mathrm{~N}$ & 30 \\
\hline
\end{tabular}

ACT: Asthma control test, NO: Nitric oxide

From Table 2, it got the coefficient of pearson correlation was the negative value that equal to -0.562 with value $\mathrm{p}<0.05$. This result concludes that there was a negative correlation significant between ACT score and NO-induced sputum level, that the higher the ACT score the lower the induced sputum NO level.
The following was the comparison of NO-induced sputum levels based on ACT score categories using one way Analysis of Variance (ANOVA).

Table 3. Comparison of NO sputum levels by ACT Score category

\begin{tabular}{|l|c|c|c|c|}
\hline \multirow{2}{*}{ ACT Score Category } & \multirow{2}{*}{ N } & \multicolumn{2}{|c|}{ NO Level $(\boldsymbol{\mu M})$} & \multirow{2}{*}{ p Value } \\
\cline { 2 - 4 } & & Mean & SD & \\
\hline Uncontrolled & 18 & 105221 & 18.011 & \multirow{2}{*}{0.00002} \\
Partially controlled & 8 & 87.523 & 19.784 & \\
Fully controlled & 4 & 41.787 & 30.600 & \\
Total & $\mathbf{3 0}$ & & & \\
\hline
\end{tabular}

ACT: Asthma control test, NO: Nitric oxide

From Table 3 we can make a comparison graph of induced sputum NO content based on ACT score category as follows. While in Figure 7 shows the average of the lowest control induced NO-induced sputum rate and the highest uncontrolled induced NO sputum content level. One way ANOVA NO-induced sputum content based on ACT score category yielded p-value $<0.05$, meaning that there was a significant difference in induced sputum NO content based on ACT score category. This result reinforces that the higher the ACT score the lower the NO-induced sputum level.
Correlation of First Forced Velocity(FEV1)/Pred, Age, and IMT with ACT Score: The following will present the results of pearson correlation between first forced velocity FEV1/Pred, age, and body mass index (BMI) with ACT scores of study subjects in Table 7 that known pearson correlation between FEV1/Pred, age, and BMI with ACT scores was $\mathrm{p}>0.05$. These concluded that there was no significant correlation between FEV1/ Pred, age, and BMI with ACT score. 
Table 4. Correlation of FEV1/Pred, age and BMI with ACT score

\begin{tabular}{|c|c|c|c|}
\hline & & & ACT Score \\
\hline \multirow{3}{*}{ Pearson Correlation } & FEV1/Pred (\%) & $\begin{array}{c}\text { Correlation Coefficient } \\
\text { Nilai } \mathrm{p} \\
\mathrm{N}\end{array}$ & $\begin{array}{c}0,051 \\
0,788 \\
30\end{array}$ \\
\hline & Age (y/o) & $\begin{array}{l}\text { Correlation Coefficient } \\
\text { Nilai } \mathrm{p} \\
\mathrm{N}\end{array}$ & $\begin{array}{c}0,081 \\
0,669 \\
30\end{array}$ \\
\hline & BMI & $\begin{array}{c}\text { Correlation Coefficient } \\
\text { P Value } \\
\text { N }\end{array}$ & $\begin{array}{c}0,036 \\
0,849 \\
30\end{array}$ \\
\hline
\end{tabular}

ACT: Asthma control test, BMI: Body mass index

Correlation of Sex, Job, and Education with ACT Score Category: The following chi-square test results were between the sexes, jobs, and education with the ACT score category in Table 8 which $p>0.05$.

Table 5. Correlation of sex, job, and educational with ACT score category

\begin{tabular}{|c|c|c|c|c|c|}
\hline & & \multicolumn{3}{|c|}{ ACT Score Category } & \multirow{2}{*}{ p Value } \\
\hline & & Uncontrolled & Partially Controlled & Fully Controlled & \\
\hline \multirow[t]{2}{*}{ Sex } & Male & 5 & 3 & 1 & \multirow[t]{2}{*}{0,859} \\
\hline & Female & & 5 & & \\
\hline \multirow{6}{*}{ Job } & Civil Servants & 3 & 0 & 0 & \multirow{6}{*}{0,058} \\
\hline & Teacher & 3 & 0 & 0 & \\
\hline & BUMN Staff & 0 & 0 & 1 & \\
\hline & Staff & 5 & 4 & 0 & \\
\hline & Pension & 1 & 3 & 1 & \\
\hline & Housewives & 6 & 1 & 2 & \\
\hline \multirow{7}{*}{ Educational } & E.S & 3 & 0 & 2 & \multirow{7}{*}{0,675} \\
\hline & J.H.S & 4 & 1 & 0 & \\
\hline & S.H.S & 5 & 5 & 1 & \\
\hline & D3 & 1 & 0 & 0 & \\
\hline & D4 & 1 & 0 & 0 & \\
\hline & S1 & 3 & 2 & 1 & \\
\hline & S2 & 1 & 0 & 0 & \\
\hline
\end{tabular}

ACT: Asthma control test

This result concludes that there was no significant relationship between sex, job, and education with the ACT score category of research subjects.

\section{Discussion}

The statistical test of the correlation between induced sputum induction and ACT score was using one way ANOVA, which showed the lowest controlled NO sputum rate, and the highest uncontrolled NO sputum level was $p<0.05$. This means that there were significant differences in induced sputum NO content based on ACT score category. These results support that the higher ACT scores the lower NO sputum level. In some studies, NO levels increased in severe asthma and uncontrolled asthma ${ }^{(19)}$. The result of the study using NO expiratory air level correlated with ACT score showed median NO in uncontrolled asthma was $40 \mathrm{ppb}$ and controlled asthma $27 \mathrm{ppb}$ also there was a statistically significant difference $(\mathrm{p}<0.002)(17)$. The ACT ratio to NO expiratory air level, the median value of NO in full 
controlled asthma was $19 \mathrm{ppb}$, in partially controlled asthma was $20 \mathrm{ppb}$, and in uncontrolled asthma was 43 ppb with statistical test result showed that overall there were significant difference ${ }^{(20)}$.

The results according to the body mass index(BMI) distribution showed the mean was 24.59 , with the lowest was 16.23 and the highest was 36.44 . There were 2 $(6.7 \%)$ subjects classified as underweight, 14 subjects as normal weight, $11(36.7 \%)$ subjects as overweight, and $3(10.0 \%)$ subjects as obese. The result of the statistical test with pearson correlation between BMI and ACT score was $p>0.05$. These results concluded that there was no significant association between BMI with ACT score. This was inconsistent with research that stated there was a significant relationship between ACT and BMI $(p=0.03)$ and asthma severity $(p=0.003){ }^{(14)}$.

This study showed the mean of first forced velocity(FEV1)/Pred was $91.1 \%$, with the lowest was $42 \%$ and the highest was $160 \%$. Statistical test with Pearson correlation states there was no correlation between FEV1/Pred value with asthma control test (ACT) score. The validated ACT was a questionnaire that performed briefly, simply, easily on its own, available, and shows continuous accuracy. In this study, the level of asthma control measured by ACT score was $18(60.0 \%)$ as uncontrolled, $8(26.7 \%)$ partially controlled, and $4(13.3 \%)$ as fully controlled. The mean ACT score of bronchial asthma subjects was $18.3 \pm 4.2$, with the lowest was 8 and the highest was 25 . The prevalence of uncontrolled asthma was greater compared to a controlled (75.7 and 24.3\%)(14). This was also consistent with research in Persahabatan Hospital consisting of uncontrolled asthma was $47(49 \%)$ higher than $41(42.7 \%)$ partially controlled asthma and $8(8.3 \%)$ fully controlled asthma(17). Similarly, the results of a study consisting of uncontrolled asthma was 12 (40\%), partially controlled was $8(26.7 \%)$, and fully controlled was $10(33.3 \%)^{(18)}$. In this study low population with full controlled asthma might cause by various factors, such as low adherence to therapy or possible resistance to treatment.

This study measured nitric oxide(NO) sputum level using the Griess method. Sputum NO concentration could be used as an inflammatory process in the respiratory tract as in asthma. Several factors might affect NO levels such as NO measurement techniques, smoking habits, genetics, infections, anti-inflammatory drugs, and nitrate-containing diets. To avoid bias, this study has been included in the criteria of inclusion and exclusion of research. All of the study subjects included in the study, asthma patients in the non-exacerbated condition and no other accompanying infections such as acute respiratory infections. The result of measurement was the average of NO concentration was $92.043 \pm 29.040$ $\mu \mathrm{M}$, with the lowest was $14.566 \mu \mathrm{M}$ and the highest was $138.350 \mu \mathrm{M}$.

The result of the variable normality test with kolmogorov smirnov was $\mathrm{p}>0.05$. This concludes that the research variable data were normally distributed, so to investigate whether there was a correlation between asthma control test (ACT) score with nitric oxide(NO) sputum content of induction was used pearson correlation. Pearson correlation coefficient is the negative value equal to -0.562 with $\mathrm{p}<0.05$. This result concludes that there was a significant negative correlation between ACT score with NO-induced sputum, the higher the ACT score the lower the NO sputum content of induction of the research subjects

\section{Conclusion}

The results showed that subjects with fully controlled asthma control were $4(13.3 \%)$ subjects, partially controlled was $8(26.7 \%)$ subjects, uncontrolled was $18(60.0 \%)$ subjects. The mean asthma control level was $18.3 \pm 4.2$, with the lowest asthma control test (ACT) score was 8 and the highest was 25 . The result of induced sputum nitric oxide (NO) level with the mean sputum measurement was $92.043 \pm 29.040 \mu \mathrm{M}$, with the lowest was $14.566 \mu \mathrm{M}$ and the highest was $138.350 \mu \mathrm{M}$. In this study, there was a significant negative correlation between induced sputum NO and asthma control ( $p$ $<0.05)$.

Conflict of Interest: There is no conflict of interest in this research.

Source of Funding: This research uses individual funding.

Ethical Clearance: This research has ethical clearance from the Faculty of Medicine, Universitas Airlangga.

\section{References}

1. Asthma Gif. Global strategy for asthma management and prevention. 2014:1-148.

2. Dasar RK. Badan Penelitian dan Pengembangan 
Kesehatan Departemen Kesehatan Republik Indonesia. 2008:1-384.

3. Ratnawati R TP. Exhaled nitric oxide in paediatric asthma. Chronic Respiratory Disease. 2005;2:16374.

4. Indonesia PDP. Pedoman Diagnosis dan Penatalaksanaan Asma di Indonesia. Jakarta: Balai Penerbit FKUI; 2004.

5. Pathogenesis OBP. In: O’Byrrompson NC. Ed. Manual of asthma management. 2nded. London: WB Saunders; 2001.

6. Smith AD CJ, Filsell S, et all. Diagnosis asthma. AM J Respir Crit Care Med. 2004;169:473-8.

7. Society AT. Recommendations for standardized procedure for the online and offline measurement of exhaled lower respiratory nitric oxide and nasal nitric oxide. Am J Respir Crit Care Med. 2005;171:912-30.

8. Sade K KS. Nitric oxide in asthma. IMAJ. 2002;4:196-8.

9. Dupon LJ DM. Prospective evaluation of the validity of exhaled nitric oxide for the diagnosis of asthma. Chest. 2003;123:751-6.

10. Barnes PJ KS. Exhaled nitric oxide: a new lung function test. Thorax. 1996;51:233-7.

11. Jang AS YC, Choi IS. Nitric oxidemetabolictes, eosinophils, and eosinophilic cationic protein in patients with asthma: sputum versus blood. J Korean Med Sci. 2003;18:489-93.

12. Jang AS CI. Nitric oxide metabolites in patients with asthma : induced sputum versus blood. Respir Med. 1999;93:912-8.

13. Chataigneau T FM, Huang PL. Acethylcholineinduced relaxation in blood vessels from endothelial nitric oxide synthase knockout mice. $\mathrm{Br}$ J Pharmacol. 1999;126:219-26.

14. Atmoko W FH, Bobian ET, et al. Prevalens asma tidak terkontrol dan faktor- faktor yang berhubungan dengan tingkat kontrol asma di poliklinik asma Rumah Sakit Persahabatan. J Respir Indo. 2011;31:53-60.

15. Toren K GT, Omenass E, et al. A prospective study of asthma incidens and its predictor: the RHINE study. Eur Respir J. 2004;24:942-6.

16. Amir M AM. Perbedaan kadar magnesium serum antara asma eksaserbasi akut dan pasca eksaserbasi. Surabaya: Departemen pulmonologi dan Kedokteran Respirasi Universitas AirlanggaRSU Dr. Soetomo; 2007.

17. MN R. Kadar nitrit oksida (NO) udara ekspirasi pada pasien asma terkontrol dan tidak terkontrol berdasarkan asthma control test (ACT) di RS Persahabatan. Jakarta: Universitas Indonesia; 2012.

18. A. F. Hubungan antara sel inflamasi sputum induksi dan tingkat kontrol asma pada penderita asma rawat jalan. Surabaya: Universitas Airlangga; 2013.

19. Shaw DE WE, Pavord ID. Exhaled nitric oxide in asthma. Eur Respir Mon. 2010;49:32-44.

20. RA A. Perubahan kadar nitrit oksida pada asma eksaserbasi dan tidak eksaserbasi di RS Persahabatan. Jakarta: Universitas Indonesia; 2012. 